\title{
RETRACTED ARTICLE: BrRNE cleaves RNA in chloroplasts, regulating retrograde signals in Brassica rapa L. ssp. pekinensis
}

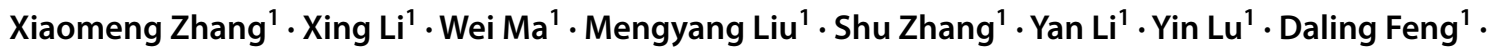 \\ Shuxing Shen ${ }^{1}$. Jianjun Zhao ${ }^{1}$ D
}

Received: 23 May 2021 / Accepted: 30 June 2021 / Published online: 22 July 2021

(c) The Author(s) 2021

The Editor-in-Chief has retracted this article because there are anomalies in the Northern blots shown in Figure 3C. The data reported in this article are therefore unreliable. The authors have been invited to submit a new manuscript for peer review. All authors agree to this retraction. The online version of this article contains the full text of the retracted article as Supplementary Information.

Supplementary Information The online version contains supplementary material available at https://doi.org/10.1007/s00122-021-03905-z.
Open Access This article is licensed under a Creative Commons Attribution 4.0 International License, which permits use, sharing, adaptation, distribution and reproduction in any medium or format, as long as you give appropriate credit to the original author(s) and the source, provide a link to the Creative Commons licence, and indicate if changes were made. The images or other third party material in this article are included in the article's Creative Commons licence, unless indicated otherwise in a credit line to the material. If material is not included in the article's Creative Commons licence and your intended use is not permitted by statutory regulation or exceeds the permitted use, you will need to obtain permission directly from the copyright holder. To view a copy of this licence, visit http://creativecommons.org/licenses/by/4.0/.

Communicated by Lixi Jiang.

Xiaomeng Zhang, Xing Li, Wei Ma These authors contributed equally to this work.

Wei Ma

mawei0720@163.com

$\triangle$ Shuxing Shen

shensx@hebau.edu.cn

$\triangle$ Jianjun Zhao

jjz1971@aliyun.com

1 State Key Laboratory of North China Crop Improvement and Regulation, Key Laboratory of Vegetable Germplasm Innovation and Utilization of Hebei, Collaborative Innovation Center of Vegetable Industry in Hebei, College of Horticulture, Hebei Agricultural University, Baoding 071000, China 